REVIEW ARTICLE

\title{
Extraction and antioxidant activity of sericin, a protein from silk
}

\section{Extração e atividade antioxidante da sericina, uma proteína da seda}

\author{
Gabriela Andrea Miguel ${ }^{1}$ (D), Catalina Álvarez-López ${ }^{2 *}$ (D) \\ ${ }^{1}$ Universidad Pontificia Bolivariana, Medellín - Colombia \\ ¿Universidad Pontificia Bolivariana, Facultad de Ingeniería Agroindustrial, Grupo de Investigaciones \\ Agroindustriales, Medellín - Colombia
}

*Corresponding Author: Catalina Álvarez-López, Universidad Pontificia Bolivariana, Facultad de Ingeniería Agroindustrial, Grupo de Investigaciones Agroindustriales, Circular 1 \# 70-01, Bloque 11, Piso 3, Medellín -

Colombia, e-mail: catalina.alvarezl@upb.edu.co

Cite as: Miguel, G. A., \& Álvarez-López, C. (2020). Extraction and antioxidant activity of sericin, a protein from silk. Brazilian Journal of Food Technology, 23, e2019058. https://doi.org/10.1590/1981-6723.05819

\begin{abstract}
Sericin is a globular protein that represents $20 \%$ to $30 \%$ of the silk fiber from Bombyx mori silkworm cocoon. This protein is usually removed from the raw fiber and discarded by silk producers, a process known as degumming. However, sericin possesses significant biological properties that allows its application in various fields. The antioxidant activity is one of its most relevant benefits. Several authors have reported its anti-tyrosinase activity, lipid peroxidation inhibition and free radical neutralization. The antioxidant potential of sericin protein varies according to the extraction method used. Even though a wide variety of extraction techniques have been studied, simple technics including water at high temperature have exhibited efficient results. Furthermore, this method does not interfere with the safety of sericin for subsequent applications in food.
\end{abstract}

Keywords: Bombyx mori; Degumming; Biological properties; Food application; Oxidative stress; Tyrosinase activity; Lipid oxidation.

\section{Resumo}

A sericina é uma proteína globular que representa entre $20 \%$ e $30 \%$ da fibra do bicho-da-seda Bombyx mori. Tem propriedades biológicas importantes, que permitem sua aplicação em vários campos, entre os quais se destaca a atividade antioxidante. Vários autores têm apontado que possui atividade anti-tirosinase, inibe a peroxidação lipídica e neutraliza os radicais livres nocivos ao corpo humano. A atividade antioxidante da sericina varia conforme o método de extração, conhecido como processo de desgomagem, e as condições de ensaio. Existem diferentes metodologias para este processo, algumas mais simples, que envolvem o uso de autoclave, e outras mais sofisticadas, como ultra e nanofiltração. A extração com água a temperaturas elevadas é eficiente e não interfere na inocuidade da sericina para aplicações subsequentes em alimentos.

Palavras-chave: Bombix mori; Desgomagem; Propriedades biológicas; Aplicação em alimentos; Estresse oxidativo; Atividade da tirosinase; Oxidação lipídica. 


\section{Introduction}

Silk is a natural fiber derived from a variety of species, including silkworms and spiders. Among these, the most studied have been the silk fiber from the Bombyx mori worm (Gonzalez et al., 2014). Silk is a protein fiber that consists of sericin and fibroin (Pescio et al., 2009). Fibroin protein comprises approximately $70 \%$ to $80 \%$ of the silk fiber. It has amorphous and crystalline domains with short amino acidic chains that allow it to maintain its compact structure (Koh et al., 2015). Sericin is a globular protein that constitutes about 20-30\% of the silk fiber. Its role is to coat and link the fibroin filaments together in the worm cocoons (Aghaz et al., 2015). Furthermore, the sericin protects the cocoon against UV radiation, wind, rain and low temperature (Cao \& Zhang, 2016). Figure 1 shows silk fibers obtained via scanning electronic microscopy (SEM). In the figure, sericin and fibroin proteins are indicated to provide a clear comprehension about the structure of the silk fiber.

A)

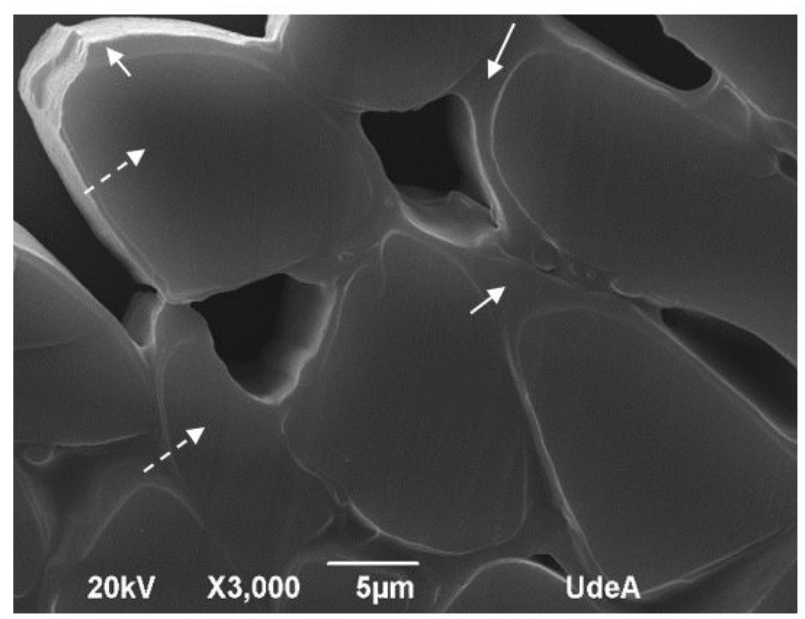

B)

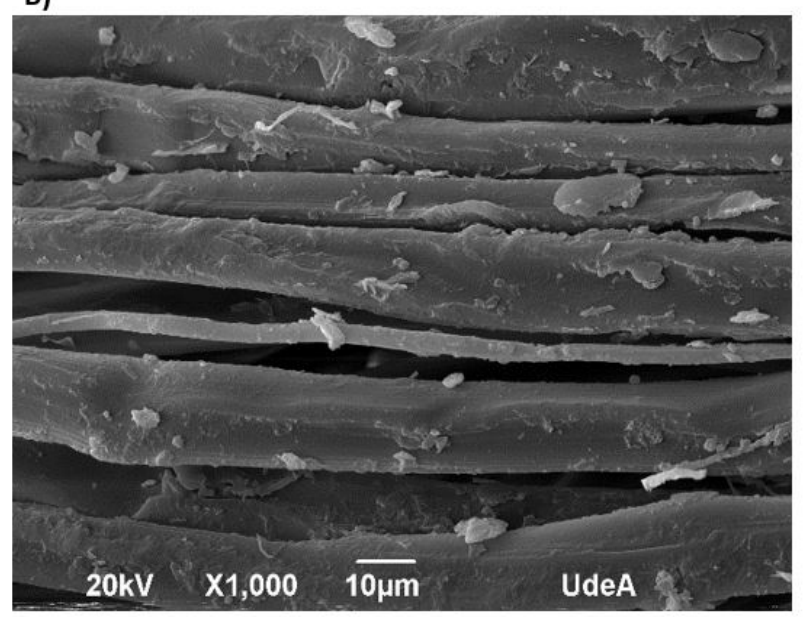

Figure 1. Silk fiber images obtained by scanning electron microscopy - SEM- in the Microscopy Department from Universidad de Antioquia (UdeA). (A) Transversal view; white solid arrows refer to the sericin which surrounds the fibroin fiber, while fibroin is indicated with white dashed arrows; (B) Longitudinal view.

The antioxidant potential of the sericin is related to its high content of amino acids with hydroxyl groups (mostly serine), which act as chelators as described in the following sections (Micheal \& Subramanyam, 2014). The presence of phenolic and flavonoid compounds in the adjacent layers of the sericin protein not 
only provide coloration to the cocoon, but they also contribute with the sericin's antioxidant activity (Aramwit et al., 2010a; Prasong, 2011; Zhao \& Zhang, 2016; Napavichayanun et al., 2017).

In the silk industry, sericin is removed from the fibroin and subsequently discarded. However, it has been shown that this protein presents interesting properties which may allow its application in several fields. Due to its moisturizing and anti-wrinkling abilities, sericin is an interesting compound to the cosmetic industry (Sothornvit et al., 2010; Züge et al., 2017). Additionally, sericin has been studied with biomedical purposes, as biomaterial and drug delivery (Cao \& Zhang, 2016; Lamboni et al., 2015; Srnivas et al., 2014; Suktham et al., 2018), mainly because it was reported to be immunologically inert (Lamboni et al., 2015). The sericin's antioxidant activity is one of the most significant property because it could provide positive effects on people health and in the food industry as a natural food preserver (Puangphet et al., 2015).

In the body, the antioxidants maintain a balance between formation and elimination of reactive oxygen species (ROS) and nitrogen. High ROS levels can be detrimental for the cell, affecting proteins, lipids and DNA, and consequently to the physiological functions of the organism. This process is known as oxidative stress (Micheal \& Subramanyam, 2014) and is associated with neurodegenerative diseases, aging, arthrosclerosis and cancer (Schinella, 2015). The human body possess an antioxidant system that involves enzymatic complexes, vitamins and other specialized molecules. In addition, there are exogenous antioxidants provided by food such as fruits, vegetables and dietary supplements, which contribute to the body antioxidant defense. These type of antioxidants becomes more relevant when the person is exposed to high levels of oxidative stress (Pisoschi \& Pop, 2015). Besides the concern of consuming antioxidants in terms of health benefits, there is a trend from the food industry to include natural antioxidants to foodstuff. This is possible because antioxidants can retard and prevent the lipid oxidation and therefore improve the food quality and its nutritional value. This approach substitutes the use of synthetic antioxidants, some of them associated to carcinogenic effects (Reddy et al., 2005; Caleja et al., 2017).

Therefore, sericin could have multiple attributes as a food ingredient due to its role in food preservation (Jassim \& Alsaree, 2010; Sarovart et al., 2003; Doakhan et al., 2013) and in human health promotion as well. Furthermore, there are evidence about other positive effects due to sericin consumption. For instance, it has been reported that sericin ameliorates the constipation in rats, it increases the intestinal mineral absorption and it also possess a prebiotic function (Patel \& Goyal, 2012). Further details about these effects are given below.

This review collects the different methods and conditions to extract sericin described in the literature and provides an updated overview of the antioxidant potential of the sericin in terms of human health and food preservation.

\section{Sericin characteristics}

Sericin protein consists of 18 different amino acids, most of them are characterized as polar. Table 1 shows the most prevalent amino acids in sericin reported in the literature. The differences observed among the authors regarding the amino acid proportion is due to the method of sericin extraction. Indeed, a study comparing the amino acid profile when using different extraction methods (alkali, acid, urea and temperature) found significant discrepancies in their ratio (Aramwit et al., 2010a). Nevertheless, all authors agreed that serine was the most abundant amino acid, followed by aspartic acid and glycine. Likewise, sericin is organized into layers: outer, middle and inner. The outer layer is the most soluble, meanwhile the layer adjacent to the fibroin can be only removed with high pressure, high temperature or alkalis compounds (Cao \& Zhang, 2016). Under these treatments $\beta$-sheet structures are degraded and consequently the protein is denaturalized, increasing thereafter its water solubility (Lamboni et al., 2015). The extraction process of sericin from the silk fiber is known as degumming. 
Table 1. Amino acid composition of the sericin protein according to the literature.

\begin{tabular}{ccccccccccc}
\hline Ser & Asp & Gly & Glut & Thr & Arg & Ala & Val & Leu & Lys & Reference \\
\hline 24.61 & 18.79 & 8.94 & 7.77 & 7.65 & 5.56 & 5.34 & 4.92 & 4.67 & Na & Li et al. (2015) \\
\hline 32.55 & 14.42 & 12.17 & 4.81 & 7.48 & 4.45 & 5.71 & 6.31 & 2.03 & 0.60 & Yang et al. (2013) \\
\hline 30.4 & 19.1 & 12.2 & 4.1 & 3.8 & 2.8 & 4.6 & 2.6 & 0.6 & 10.2 & Sasaki et al. (2000) \\
\hline 31.0 & 17.8 & 19.1 & 4.4 & 8 & 3.9 & 3.8 & 3.1 & 0.8 & 2.7 & Kato et al. (1998) \\
\hline 25.5 & 18.38 & 17.85 & 5.74 & 7.47 & 3.12 & 6.70 & 4.05 & 1.49 & 2.08 & Cao \& Zhang (2016) \\
\hline 28.89 & 19.81 & 10.75 & 6.98 & 7.81 & 4.39 & 4.65 & 3.12 & 1.12 & 3.51 & Li et al. (2008) \\
\hline 32.74 & 17.64 & 9.89 & 7.31 & 5.51 & 6.16 & 3.86 & 3.14 & 1.44 & 3.05 & Sothornvit et al. (2010) \\
\hline 21.56 & 14.0 & 23.20 & 3.30 & 7.04 & 11.95 & $\mathrm{Na}$ & 3.36 & 2.08 & 3.18 & Züge et al. (2017) \\
\hline 33.73 & 20.82 & 9.53 & 4.98 & 8.57 & 5.22 & $1-3$ & $1-3$ & $\mathrm{Na}$ & $1-3$ & Puangphet et al. (2015) \\
\hline 25.55 & 17.33 & 8.23 & 5.79 & 5.04 & 3.48 & 2.80 & 2.57 & 0.92 & 3.14 & Wu et al. (2008) \\
\hline 37.3 & 14.8 & 14.7 & 3.4 & 8.7 & 3.6 & 4.3 & 3.6 & 1.4 & 2.4 & Gonzalez et al. (2014) \\
\hline
\end{tabular}

Values are shown in Mol (\%). Ser = serine, Asp = asparagine, Gly = glicine, Glut = glutamine, $\mathrm{Thr}=$ threonine, $\mathrm{Arg}=$ arginine, Ala = alanine, $\mathrm{Val}=$ valine, Leu $=$ leucine, Lys $=$ lysine, $\mathrm{Na}=$ not available data.

\section{Extraction methods of sericin}

A great diversity of extraction methods has been studied, either from wastewater provided by silk industries or directly from the silk fiber. Sericin characteristics, such as purity, molecular weight, antioxidant activity and biochemical properties, vary according to the method used (Aramwit et al., 2010a, 2010b; Li et al., 2008). After extraction, molecular weights from $10 \mathrm{kDa}$ to $310 \mathrm{kDa}$ have been reported (Kumar et al., 2015). Most of the extraction methods existing in the literature are enumerated in Table 2.

Table 2. Methods and conditions described in the literature to extract sericin.

\begin{tabular}{|c|c|c|c|}
\hline Extraction method & Condition of extraction & Outcome & References \\
\hline \multirow{7}{*}{$\begin{array}{l}\text { Denaturing agents } \\
\text { (boiling with } \\
\text { detergents, alkaline } \\
\text { compounds and } \\
\text { chaotropic agents) }\end{array}$} & Urea $(8 \mathrm{M})$ for $30 \mathrm{~min}$ & $\begin{array}{c}10 \text { to }>225 \mathrm{kDa} \text { sericin size, } \\
18 \% \text { to } 20 \% \text { yield. }\end{array}$ & \multirow{2}{*}{$\begin{array}{l}\text { Aramwit et al. (2010a) } \\
\text { Aramwit et al. (2010b) }\end{array}$} \\
\hline & $\begin{array}{l}\text { Sodium carbonate }(0.5 \%) \text { for } \\
30 \mathrm{~min} \text {. }\end{array}$ & $\begin{array}{c}15 \text { to } 75 \mathrm{kDa} \text { sericin size, } \\
6 \% \text { to } 12 \% \text { yield. }\end{array}$ & \\
\hline & $\begin{array}{l}\text { Sodium oleate }(0.3 \%) \text { and } \\
\text { sodium carbonate }(0.2 \%) \text { for } \\
60 \text { min. }\end{array}$ & $\begin{array}{l}\text { High-purity sericin was } \\
\text { recovered with calcium chloride }\end{array}$ & Yang et al. (2013) \\
\hline & $\begin{array}{c}\text { Calcium hydroxide }(0.025 \%) \text { for } \\
40 \text { min and neutralization with } \\
\text { acids }\end{array}$ & $\begin{array}{c}<20 \mathrm{kDa} \text { sericin size, more than } \\
85 \% \text { recovery }\end{array}$ & Zhao et al. (2018), \\
\hline & $\begin{array}{c}\text { Novel surfactant based on silk } \\
\text { amino acids and lauryl chloride } \\
(0.2 \%) \text { for } 30 \mathrm{~min} \text {. }\end{array}$ & $\begin{array}{c}\text { Similar quality when using } \\
\text { neutral soap, but eco-friendlier } \\
\text { agent }\end{array}$ & Wang et al. (2015) \\
\hline & Neutral soap $(0.2 \%)$ & Longer processing time. & Wang et al. (2015) \\
\hline & $\begin{array}{l}\text { Coconut soap and sodium } \\
\text { bicarbonate for } 45 \text { min. } \\
\text { Precipitation with } 75 \% \text { ethanol } \\
\text { after drying. }\end{array}$ & $\begin{array}{c}74.5 \% \text { yield from silk } \\
\text { wastewater, } 63.8 \% \text { sericin } \\
\text { purity }\end{array}$ & Álvarez et al. (2013) \\
\hline \multirow{4}{*}{ Enzymatic digestion } & $\begin{array}{c}\text { Commercial proteolytic } \\
\text { enzymes for } 5-240 \text { min. at } 50-65 \\
{ }^{\circ} \mathrm{C}\end{array}$ & $\begin{array}{c}5 \text { to } 20 \mathrm{kDa} \text { sericin size with a } \\
\text { weight-average molecular } \\
\text { weight of about } 12 \mathrm{kDa}\end{array}$ & Freddi et al. (2003) \\
\hline & $\begin{array}{l}\text { Novel protease isolated from } \\
\text { Bacillus sp. }\end{array}$ & \multirow{3}{*}{$\begin{array}{l}\text { Efficient degumming, sericin } \\
\text { was not characterized }\end{array}$} & $\begin{array}{c}\text { Suwannaphan et al. } \\
(2017)\end{array}$ \\
\hline & Alcalase and Savinase at $55^{\circ} \mathrm{C}$ & & Arami et al. (2007) \\
\hline & $\begin{array}{c}\text { Alcalase/Savinase and } \\
\text { ultrasound }\end{array}$ & & Mahmoodi et al. (2010) \\
\hline Infrared rays & $\begin{array}{l}\text { IR heating extraction from silk } \\
\text { wastewater }\end{array}$ & $\begin{array}{c}21 \% \text { to } 26 \% \text { yield, a clean } \\
\text { sericin is obtained, eco-friendly } \\
\text { process }\end{array}$ & Gupta et al. (2013) \\
\hline
\end{tabular}


Table 2. Continued...

\begin{tabular}{|c|c|c|c|}
\hline Extraction method & Condition of extraction & Outcome & References \\
\hline Polymeric membranes & $\begin{array}{l}\text { Membrane of polysulfone in by } \\
\text { phase inversion with } \\
\text { polydioxolane and polyethylene } \\
\text { glycol }\end{array}$ & $\begin{array}{l}10 \mathrm{kDa}-250 \mathrm{kDa} \text { sericin size } \\
\text { recovered from silk wastewater }\end{array}$ & Sonjui et al. (2009) \\
\hline \multirow{10}{*}{ Steam (Autoclave) } & $\begin{array}{l}120^{\circ} \mathrm{C} \text { for } 60 \mathrm{~min} \text {. The liquor } \\
\text { ratio was } 1: 25 \text {. Sericin was } \\
\text { concentrated by rotavapor. }\end{array}$ & $\begin{array}{c}\text { A film made of glycerol/sericin } \\
\text { was satisfactorily carried out to } \\
\text { assess its use as a polymeric } \\
\text { material. }\end{array}$ & Yun et al. (2016) \\
\hline & $\begin{array}{c}82-120^{\circ} \mathrm{C} \text { (above } 105^{\circ} \mathrm{C} \text { using } \\
\text { autoclave) and time in the range } \\
\text { of } 10-60 \text { min. Separation by } \\
\text { hydraulic pressing at } 2.5 \mathrm{MPa} \\
\text { for } 1 \text { min and drying. }\end{array}$ & $\begin{array}{l}\text { Extracted sericin exhibited } \\
\text { mainly serine }(18.24 \%) \text { and } \\
132 \mathrm{kDa} \text { molecular size. } \\
\text { Effective to film formation. }\end{array}$ & Sothornvit et al. (2010) \\
\hline & $70-65^{\circ} \mathrm{C}$ for $60 \mathrm{~min}$. & $\begin{array}{c}\text { Total phenolic compound } \\
\text { correlated with amount of } \\
\text { sericin extracted. } \\
\end{array}$ & Prasong (2011) \\
\hline & $\begin{array}{l}\text { Autoclaved at } 121^{\circ} \mathrm{C} \text { for } \\
30 \mathrm{~min} / 45 \mathrm{~min} / 60 \mathrm{~min} .\end{array}$ & $\begin{array}{l}16 \text { to } 44 \mathrm{kDa} \text { molecular size. } \\
\text { Clean product. Lower yield } \\
\text { compared to alkaline extraction. }\end{array}$ & Srnivas et al. (2014) \\
\hline & $\begin{array}{l}\text { Autoclaved } 120^{\circ} \mathrm{C} \text { for } 60 \mathrm{~min} \\
\text { and dried by spray- drying. }\end{array}$ & $\begin{array}{l}\text { Sericin microparticles with an } \\
\text { average diameter }<10 \mu \mathrm{m} \text { were } \\
\text { obtained. }\end{array}$ & Chlapanidas et al. (2013) \\
\hline & Autoclaved $120^{\circ} \mathrm{C}$ for $60 \mathrm{~min}$ & $\begin{array}{c}\text { Higher thermal stability } \\
\text { compared with urea and alkaline } \\
\text { extraction methods. }\end{array}$ & Aramwit et al. (2010b) \\
\hline & $\begin{array}{l}\text { Autoclaved } 120^{\circ} \mathrm{C} \text { for } 60 \mathrm{~min} \\
\text { and lyophilization or freezing- } \\
\text { thawing precipitation }\end{array}$ & $\begin{array}{l}20 \mathrm{kDa} \text { to } 400 \mathrm{kDa} \text { sericin size. } \\
\text { Radical scavenging effect and } \\
\text { antibacterial. }\end{array}$ & Rocha et al. (2017) \\
\hline & $\begin{array}{c}\text { Autoclaved at } 121^{\circ} \mathrm{C} \text { for } \\
30 \mathrm{~min} \text {, filtered and dialyzed }\end{array}$ & $\begin{array}{l}\text { Sericin as biomaterial is } \\
\text { assessed. }\end{array}$ & Chirila et al. (2013) \\
\hline & $\begin{array}{c}\text { Autoclaved at } 121^{\circ} \mathrm{C} \text { for } \\
30 \mathrm{~min} \text {, and a liquor ratio } \\
\text { 1:30 (w/v), filtered and } \\
\text { lyophilized. }\end{array}$ & $\begin{array}{l}\text { Source of sericin extraction } \\
\text { (cocoons or yarns) affects the } \\
\text { final product. }\end{array}$ & $\begin{array}{l}\text { Castrillón Martínez et al. } \\
\text { (2017) }\end{array}$ \\
\hline & $\begin{array}{c}\text { Steam } 120^{\circ} \mathrm{C} \text { for } 60 \mathrm{~min} \text { and } \\
\text { precipitation with ethanol at } \\
\text { various ratios. }\end{array}$ & $\begin{array}{c}\text { Precipitation of hydrophobic SS } \\
\text { and removal of low molecular } \\
\text { weight SS, enhanced } \\
\text { mechanical stability }\end{array}$ & Oh et al. (2011) \\
\hline \multirow{3}{*}{$\begin{array}{l}\text { Ultrafiltration- } \\
\text { Nanofiltration }\end{array}$} & $\begin{array}{l}\text { Silk wastewater was } \\
\text { centrifuged, crystallized and } \\
\text { ultrafiltered with } \\
\text { polyethersulfone membranes }\end{array}$ & $\begin{array}{l}\text { Sericin is separated from fatty } \\
\text { acids derived from soaps added } \\
\text { during industrial degumming. }\end{array}$ & Capar et al. (2009) \\
\hline & $\begin{array}{c}\text { Hollow fiber nanofiltration } \\
\text { membrane integrated with } \\
\text { ultrafiltration }\end{array}$ & $\begin{array}{c}86 \% \text { sericin from cocoon silk } \\
\text { wastewater could be recovered. } \\
\text { Isolated sericin was not } \\
\text { characterized. }\end{array}$ & Li et al. (2015) \\
\hline & $\begin{array}{l}\text { Autoclaved and recovery by } \\
\text { ultrafiltration with hollow fiber } \\
\text { membrane of polyethersulfone }\end{array}$ & $\begin{array}{c}\text { High molecular sericin is } \\
\text { obtained }\end{array}$ & $\begin{array}{l}\text { Silva et al. (2012), } \\
\text { Gimenes et al. (2014) }\end{array}$ \\
\hline
\end{tabular}

\subsection{Extraction with detergents and alkaline compounds}

Detergents and soaps lead to protein denaturalization and partial hydrolysis of the silk filament chains (Cao \& Zhang, 2016). Sodium carbonate (Aramwit et al., 2010b; Yang et al., 2013), calcium hydroxide (Zhao et al., 2018) and non-ionic detergents (Mahmoodi et al., 2010) have been utilized for the degumming process. Even though this method is widely used by silk processing industries, it is considered as a non- desired approach due to the presence of these alkaline compounds in the residual water (Wang et al., 
2015; Mahmoodi et al., 2010). Furthermore, the subsequent isolation of the sericin from the detergent is a complex process (Lamboni et al., 2015).

\subsection{Extraction with steam using autoclave}

This process consists of the removal of sericin through high temperature and pressure. Due to the high temperature applied, hydrogen bonds between hydroxyl groups become unstable allowing the water to interact with polar amino acids of the sericin (Silva et al., 2012). The molecular weight of the samples obtained is in the range of 27 to $200 \mathrm{kDa}$ (Rocha et al., 2017). This method is quite simple, likewise a good quality and clean product is attained (Lamboni et al., 2015). However, some studies argue that this method could degrade the sericin protein. Furthermore, factors such as the temperature and the extraction time are involved in the variation of the molecular weight obtained (Oh et al., 2011; Silva et al., 2012). The yield obtained through the use of steam is lower compared to extraction by alkaline compounds (for instance, $0.5 \%$ calcium carbonate) (Srnivas et al., 2014). On the other hand, the absence of chemical compounds and the lower water consumption that required this method, contribute positively to the environment and consequently, to the sustainable feature of the method (Wang et al., 2018).

\subsection{Extraction with enzymes}

This process comprises the elimination of sericin from the silk fiber assisted with proteolytic enzymes. Alkaline and neutral proteases have shown an efficient degumming. After removed, sericin is recovered by drying. The enzyme dosage and treatment time influence the kinetics of the process. Moreover, chemical properties of soluble sericin peptides varies as according to the enzyme utilized. Peptides in the range of 5 to $20 \mathrm{kDa}$ are obtained and these are free of alkali and fatty acids (Freddi et al., 2003). Whereas this approach is slightly more expensive than the technics described above, less energy is required. Consequently, this process becomes more sustainable (Wang et al., 2018). The combined use of enzymes (savinase and alcalase) and ultrasound to extract the sericin from the silk fiber was also assessed. In this case, the efficacy of the degumming process increased along the treatment time. However, the integrity of the sericin isolated have not been studied by the authors (Mahmoodi et al., 2010). Interestingly, an extracellular protease isolated from Bacillus sp. has shown a high specificity to remove sericin from the silk at a $\mathrm{pH}$ slightly alkaline. The peptides obtained from the proteolytic activity by the purified enzyme consists in 10 to $12 \mathrm{kDa}$ (Suwannaphan et al., 2017). Similarly, a thermostable alkaline serine protease from a bacterium (Bacillus hallodurans) capable of remove sericin from the silk was recently isolated. This novel protease has exhibited a higher degumming ability than commercial alcalase proteases (Yakul et al., 2019).

\subsection{Other methods}

More sophisticated technics have also been studied. For instance, a process that combines acid precipitation, ultrafiltration and nanofiltration revealed an efficient performance. The sericin from industrial degumming water was recovered up to $86 \%$ through this complex technique (Cao \& Zhang, 2016; Li et al., 2015). Other techniques use infrared rays and presents additional advantages such as the use of lower temperatures, it does not use as much water as other methods, and superior yield is obtained. However, if greater amounts need to be recovered, the process costs are higher. Further extraction methods such as sonication and the use of polymeric membrane have also been studied by a few authors (Mahmoodi et al., 2010; Sonjui et al., 2009).

\section{Antioxidant activity of sericin protein}

several studies have demonstrated that isolated sericin prevents oxidative stress and lipidic peroxidation (Kato et al., 1998; Micheal \& Subramanyam, 2014; Chlapanidas et al., 2013; Takechi et al., 2014; Khyade, 
2016; Napavichayanun et al., 2017; Deori et al., 2016; Sangwong et al., 2016; Kumar \& Mandal (2017); Fan et al., 2010; Kaewkon et al., 2012; Zhaorigetu et al., 2001; Dash et al., 2008), and inhibits tyrosinase activity (Aramwit et al., 2010a; Kato et al., 1998; Thongsook \& Tiyaboonchai, 2011; Puangphet et al., 2015; Wu et al., 2008; Manosroi et al., 2010). Table 3 provides an overview of studies supporting the sericin's antioxidant activity.

\subsection{The role of sericin against lipid oxidation}

The reaction between a polyunsaturated lipid and oxygen is known as lipid peroxidation. The secondary products, which result from this process are not only harmful for the cellular metabolism, but they also alter the quality of food, modifying the texture, flavor and even the color in some occasions (Samaranayaka \& Li-Chan, 2011).

Several studies were carried out to investigate the protective role of the sericin in cell tissues. Kato et al. (1998), studied the sericin's antioxidant activity by observing the inhibition of the lipid peroxidation in homogenized brain extracts from mice treated with sericin. They found that those tissues incubated with sericin for longer time, presented a low number of products derivate from lipid peroxidation when comparing with control, where higher oxidation was observed (Kato et al., 1998). A similar study was performed by Khyade (2016), by using feline fibroblasts previously treated with hydrogen peroxide to induce oxidative stress. The samples incubated with sericin also exhibited a remarkable lower concentration of products from lipid peroxidation in this experiment when comparing with the non-sericin treated tissue (Khyade, 2016).

The protective function of sericin on lipid oxidation in foodstuff was likewise investigated. Fan et al. (2009) studied the effect of sericin in the inhibition of lipid peroxidation, specifically in linoleic acid. For this purpose, sericin was extracted by hot water, filtered and lyophilized. They found an inhibition of approximately $80 \%$ of peroxides from linoleic acid, being this effect potentially higher than the synthetic antioxidant butylated hydroxytoluene (BHT) (Fan et al., 2009). These findings suggest that sericin prevents the oxidation process in which lipids are involve. Furthermore, as it commented in the following section, it inhibits the enzyme tyrosinase, responsible of the oxidation process that causes the browning of some fruits and vegetables.

\subsection{Effect of sericin in the inhibition of tyrosinase activity}

Among the antioxidant mechanism of the sericin, the inhibition of the tyrosinase activity has been widely studied. Tyrosinase enzyme, also known as poliphenoloxidase, catalyzes the hydroxylation from monophenols to diphenols and the oxidation of these to quinones. This process results in the formation of melanin, which causes the browning effect observed in some fruits and vegetables (Xing et al., 2016). The fact that tyrosinase is also implicated in diseases such as cancer and Parkinson, causes that compounds with possible anti- tyrosinase effects are being widely investigated either for biomedical or food applications (Aramwit et al., 2010a; Xing et al., 2016).

Several studies have reported anti-tyrosinase activity of sericin from cocoons belonging to different strains and from different extraction methods as well. Aramwit et al. (2010a) compared the inhibition of the tyrosinase when sericin from Bombyx mori was extracted by four different methods: urea, temperature, acid and alkaline compounds. The extraction with urea exhibited the highest anti-tyrosinase activity. This might be caused by the large amounts of valine and arginine amino acids that results from this extraction, which are known to have more affinity to bound to tyrosinase enzyme and inhibit it. On the contrary, peptides with larger proportion of tyrosine, act as a substrate for the enzyme, thus promoting its oxidative activity (Aramwit et al., 2010a). Kato et al. (1998) measured the tyrosinase activity from a mushroom enzyme when incubating with $1 \%$ and $0.5 \%$ sericin, which was previously extracted by hot water, filtered and spray dried. They found an inhibition of $50 \%$ and $25 \%$ of the tyrosinase activity with $1 \%$ and $0.5 \%$ of sericin respectively 
(Kato et al., 1998). Interestingly, the influence of worm's feed, either artificial or natural, and the worm strain on the sericin anti-tyrosinase activity, was further investigated by Chlapanidas et al. (2013). 20 strains were analyzed. Among these Nistari, ADPR, Sajaku Green BG and Daizo presented the highest antioxidant activity with a $60 \%$ to $80 \%$ of tyrosinase inhibition compared to positive control (100\%). Regarding to the type of feed, worms fed with fresh mulberry leaves showed to increase this potential. Therefore, both strain and feed have an effect on the anti-tyrosinase activity (Chlapanidas et al., 2013).

Similarly, biopeptides of sericin, obtained by enzymatic hydrolysis, exhibited a higher antioxidant potential compared to non-hydrolyzed sericin (Wu et al., 2008; Puangphet et al., 2015, 2018). According to Puangphet et al. (2018), sericin biopeptides containing larger amounts of serine and asparagine present the most inhibitory effect (Puangphet et al., 2018). The type of protease used for the hydrolysis also influences the effect, where alcalase showed the best performance (Fan et al., 2010). The authors suggest that the reason behind the increase of the anti-tyrosinase activity observed with hydrolyzed sericin, is the metal-chelating ability. Since tyrosinase enzyme requires copper ions to be active (Puangphet et al., 2015), the sericin binds to the copper atoms of tyrosinase enzyme, and therefore its oxidant activity is blocked. This effect is due to the presence of a high content of amino acids with hydroxyl groups, such as serine, asparagine and threonine acting as chelators (Micheal \& Subramanyam, 2014). Furthermore, the hydrophobic section of these amino acids might contribute to their binding in the hydrophobic pocket near the active site of tyrosinase, causing its inhibition (Puangphet et al., 2018). These findings make the sericin an interesting candidate to retard the browning effect in foodstuff without the addition of synthetic antioxidant compounds.

\subsection{Sericin effect in Reactive Oxygen Species (ROS)}

It has been shown that sericin has a scavenger effect, stabilizing free radicals, which are responsible of oxidative damage (Micheal \& Subramanyam, 2014; Chlapanidas et al., 2013; Takechi et al., 2014; Li et al., 2008). Chlapanidas et al (2013) found a ROS-scavenging activity of $80 \%$ exerted by sericin extracted from Bombyx mori cocoon when compared to a positive control (100\%) (Chlapanidas et al., 2013). Li et al. (2008) observed that sericin partially reverted the oxidative stress induced by alcohol in mice liver (Li et al., 2008). Manosroi et al. (2010) compared the sericin scavenger ability when it was extracted using autoclave and through a hydrolysis with alkaline compounds. The most effective effect was shown with the last named technique where the antioxidant activity was even higher than those obtained with $\mathrm{C}$ and $\mathrm{E}$ vitamins (Manosroi et al., 2010). Moreover, there was found an inverse relation between the sericin molecular size and the antioxidant activity. When sericin size decreased by the action of proteases, the scavenger activity increased (Sangwong et al., 2016). In a recent study, the radical scavenging activity of a sericin extract obtained by a novel isolated bacterial protease was compared with a sericin extract produced by a commercial alcalase. The antioxidant potential from the bacterial purified protease was significantly higher than those treated with a commercial protease (Yakul et al., 2019).

\subsection{Effect of sericin in colon cancer}

Sericin protein is resistant to human proteases, subsequently, it reaches intact to the rectal zone (Kaewkorn et al., 2012). Because of this characteristic, the influence of sericin in colon cancer was investigated. Two studies performed in mice found a correlation between the ingestion of sericin and a positive effect in the incidence of colon tumors (Zhaorigetu et al., 2001; Kaewkon et al., 2012). Zhaorigetu et al. (2001) histologically investigated the anti-tumoral function of sericin in colon cell and its relationship with the antioxidant activity of sericin. For this purpose, colon tumorigenesis was induced in mice, and the animals were treated orally with sericin. The cellular proliferation and the oxidative stress analyses of the target tissue revealed a lower tumor incidence and a minor oxidative stress compared with the control group, where mice were fed with casein protein instead of sericin (Zhaorigetu et al., 2001). 
Similarly, Kaewkorn et al. (2012) found that 5 out of 14 control mice with induced colon cancer developed tumors. Meanwhile 1 out of 14 mice, which were fed with a diet rich in sericin, presented tumors in colon. Furthermore, they found a reduction of colonic lipid oxidation. The authors suggest that these findings might be due to a suppression activity exerted by sericin of the initiation and promotion stages of colon tumorigenesis (Kaewkon et al., 2012). The effect was also evaluated in human carcinogenic colon cells by an incubation of these cells with increasing concentrations of sericin varying in its molecular size as well. As a consequence, a lower cell viability in samples treated with smaller size of sericin was observed. According the authors, this result can be awarded to an anti-proliferative effect of the sericin by inducing cell apoptosis (Kaewkorn et al., 2012).

These studies suggest a positive influence by the sericin in colon cancer, even though more studies are necessary to establish a solid relation between sericin treatment and incidence of colon cancer.

\subsection{Effect of sericin on oxidative stress in epidermis tissues}

Skin cells are in constant contact with oxygen and frequently exposed to solar radiation. This fact gives rise to the increase of ROS and consequently the incidence of skin cancer (Zhaorigetu et al., 2003). Zhaorigetu et al. (2003) and Dash et al. (2008) investigated the possible role of the sericin in controlling oxidative stress in epidermis cells. For this aim, they used as in vivo model mice exposed to skin carcinogenic agents and feline fibroblasts with damage induced by a pro-oxidant, such as $\mathrm{H}_{2} \mathrm{O}_{2}$, as in vitro assay (Zhaorigetu et al., 2003; Dash et al., 2008; Khyade, 2016). It was found that only $10 \%$ of mice treated topically with sericin developed tumors after being exposed to carcinogenic agents (Zhaorigetu et al., 2003). When analyzing the effect of the sericin on $\mathrm{H}_{2} \mathrm{O}_{2}$-induced DNA damaged in feline fibroblasts, an increase in the cellular viability for sericin-treated cells was obtained. The survival observed was proportional to the amount of sericin used (Dash et al., 2008). Moreover, an attenuated release of catalase, enzyme that catalyzes the decomposition of $\mathrm{H}_{2} \mathrm{O}_{2}$, was found in sericin-treated samples. These findings suggest a protective effect from sericin protein against oxidative stress (Dash et al., 2008). Similar results were obtained by Kumar \& Mandal (2017) when analyzing the protective function of sericin against oxidative stress in mouse fibroblasts with $\mathrm{H}_{2} \mathrm{O}_{2}$-induced cell damage. The influence on the antioxidant effect of the extraction method of sericin from the silk was also studied. The extraction by using steam exhibited a better protection and cell recovery as well, compared with other methods such as urea, alkali, acid and conventional (hot water) treatments (Kumar \& Mandal, 2017).

Overall these experiments, both in vitro and in vivo, suggests that sericin protein has a suppressor role in skin tumorigenesis by a reduction of the oxidative stress in the epidermis cells. Thus, sericin topically treatments could be an interesting point to research with biomedical application purposes.

Table 3. Literature about antioxidant activity of sericin protein.

\begin{tabular}{|c|c|c|c|}
\hline $\begin{array}{l}\text { Antioxidant } \\
\text { assay }\end{array}$ & Target & Comments & Reference \\
\hline \multirow{5}{*}{$\begin{array}{l}\text { Lipid } \\
\text { peroxidation }\end{array}$} & Feline fibroblasts & $\begin{array}{l}\text { Locally treated (pre-incubation) for } 24 \mathrm{hs} \text {. } \\
\text { Effect observed at } 100 \mathrm{ng} / \mathrm{mL} \text {. }\end{array}$ & Khyade (2016) \\
\hline & $\begin{array}{l}\text { Brain and peripheral rat } \\
\text { tissues }\end{array}$ & $\begin{array}{l}\text { Oral via, } 0.25 \text { and } 0.5 \mathrm{gm} / \mathrm{kg} \text { body weight } \\
\text { (b.w.)/day of CSE for a period of } 28 \text { days. }\end{array}$ & Deori et al. (2016) \\
\hline & Rat brain & $\begin{array}{l}\text { Locally treated (pre-incubation), } 0.3 \% \\
\text { sericin for } 30 \text { to } 200 \mathrm{~min} .\end{array}$ & Kato et al. (1998) \\
\hline & Mouse fibroblast (L929) cells & $\begin{array}{l}\text { Locally treated (pre-incubation), } \\
10 \text { and } 100 \mu \mathrm{g} / \mathrm{mL} \text { sericin. }\end{array}$ & $\begin{array}{c}\text { Kumar \& Mandal } \\
\text { (2017) }\end{array}$ \\
\hline & $\begin{array}{c}\text { Skin fibroblast cell line } \\
\text { (AH927) damaged by } \mathrm{H}_{2} \mathrm{O}_{2}\end{array}$ & $\begin{array}{l}\text { Locally treated (pre-incubation) for } 24 \mathrm{~h} \text {. } \\
\text { Positive effects in cell viability is observed }\end{array}$ & Dash et al. (2008) \\
\hline
\end{tabular}


Table 3. Continued...

\begin{tabular}{|c|c|c|c|}
\hline $\begin{array}{l}\text { Antioxidant } \\
\text { assay }\end{array}$ & Target & Comments & Reference \\
\hline & & $\begin{array}{l}\text { for } B . \text { mori and lipid peroxidation for } A . \\
\text { mylitta. }\end{array}$ & \\
\hline & $\begin{array}{l}\text { Larvae mid-gut cell } \\
\text { homogenate }\end{array}$ & Locally treated (pre-incubation). & $\begin{array}{c}\text { Micheal \& } \\
\text { Subramanyam } \\
\quad(2014)\end{array}$ \\
\hline \multirow{7}{*}{$\begin{array}{l}\text { Tyrosinase } \\
\text { activity }\end{array}$} & $\begin{array}{c}\text { Tyrosinase mushroom } \\
\text { solution }(100 \text { Units } / \mathrm{mL})\end{array}$ & $\begin{array}{l}0.8 \mathrm{mg} \text { sericin. Sericin extracted by Urea } \\
\text { presented the highest antioxidant effect. }\end{array}$ & $\begin{array}{l}\text { Aramwit et al. } \\
(2010 \mathrm{a})\end{array}$ \\
\hline & \multirow{5}{*}{$\begin{array}{l}\text { Tyrosinase mushroom } \\
\text { solution }\end{array}$} & Hydrolyzed sericin at $5 \%$. & $\begin{array}{l}\text { Puangphet et al. } \\
(2015)\end{array}$ \\
\hline & & $0.5 \%$ and $1 \%$ sericin. & Kato et al. (1998) \\
\hline & & Sericin at doses of $6.4,3.2,1.6 \mathrm{mg} / \mathrm{mL}$. & $\begin{array}{c}\text { Chlapanidas et al. } \\
\text { (2013) }\end{array}$ \\
\hline & & Hydrolyzed sericin at 1.2 to $10 \mathrm{mg} / \mathrm{mL}$. & Wu et al. (2008) \\
\hline & & $\begin{array}{l}\text { Sericin extracted by basic hydrolysis } \\
\text { exhibited the best performance. }\end{array}$ & $\begin{array}{l}\text { Manosroi et al. } \\
(2010)\end{array}$ \\
\hline & $\begin{array}{c}\text { Tyrosinase mushroom } \\
\text { solution, Tyrosinase apple } \\
\text { solution, Tyrosinase banana } \\
\text { solution, Tyrosinase bean } \\
\text { sprouts solution } \\
\end{array}$ & Hydrolyzed sericin at $5 \%$. & $\begin{array}{l}\text { Puangphet et al. } \\
\text { (2018) }\end{array}$ \\
\hline \multirow{4}{*}{$\begin{array}{l}\text { ROS (Reactive } \\
\text { oxygen species) }\end{array}$} & $\begin{array}{c}\text { Skin fibroblast cell line } \\
\text { (AH927) damaged by } \mathrm{H}_{2} \mathrm{O}_{2}\end{array}$ & Locally treated (pre-incubation) for $24 \mathrm{~h}$. & Dash et al. (2008) \\
\hline & Catalase activity (CAT) & Sericin at 10 and $100 \mu \mathrm{g} / \mathrm{mL}$ & $\begin{array}{c}\text { Kumar \& Mandal } \\
(2017) \\
\end{array}$ \\
\hline & $\begin{array}{l}\text { Brain and peripheral rat } \\
\text { tissues }\end{array}$ & $\begin{array}{l}\text { Glutathione (GSH) and superoxide } \\
\text { dismutase (SOD) analyzed as oxidative } \\
\text { stress markers. }\end{array}$ & Deori et al. (2016) \\
\hline & $\begin{array}{l}\text { Larvae mid-gut cell } \\
\text { homogenate }\end{array}$ & CAT and SOD analyzed. & $\begin{array}{c}\text { Micheal \& } \\
\text { Subramanyam } \\
(2014) \\
\end{array}$ \\
\hline \multirow{3}{*}{$\begin{array}{l}\text { FRAP (Ferric } \\
\text { ion reducing } \\
\text { antioxidant } \\
\text { power assay) }\end{array}$} & \multirow{3}{*}{ Biochemical assay } & Sericin at $1 \mathrm{mg} / \mathrm{mL}$. & $\begin{array}{c}\text { Kumar \& Mandal } \\
(2017)\end{array}$ \\
\hline & & $\begin{array}{l}\text { Mulberry and non-mulberry strains were } \\
\text { analyzed. }\end{array}$ & $\begin{array}{c}\text { Butkhup et al. } \\
\text { (2012) }\end{array}$ \\
\hline & & Sericin hydrolysate with bacterial protease & Yakul et al. (2019) \\
\hline \multirow{3}{*}{$\begin{array}{c}\text { ABTS } \\
\text { (2,2-azino-bis (3- } \\
\text { ethylbenzothiazo } \\
\text { line-6-sulphonic } \\
\text { acid) } \\
\end{array}$} & \multirow{3}{*}{ Biochemical assay } & $\begin{array}{l}\text { Hot water extraction at different times was } \\
\text { studied. }\end{array}$ & $\begin{array}{l}\text { Sangwong et al. } \\
(2016)\end{array}$ \\
\hline & & $\begin{array}{c}\text { Mulberry and non-mulberry strains were } \\
\text { analyzed. }\end{array}$ & $\begin{array}{l}\text { Butkhup et al. } \\
\text { (2012) }\end{array}$ \\
\hline & & Sericin hydrolysate with bacterial protease & Yakul et al. (2019) \\
\hline \multirow{4}{*}{$\begin{array}{c}\text { DPPH } \\
\text { (2,2-diphenyl-1- } \\
\text { picrylhydrazyl) }\end{array}$} & \multirow{4}{*}{ Biochemical assay } & $\begin{array}{l}\text { Mulberry and non-mulberry strains were } \\
\text { analyzed. }\end{array}$ & $\begin{array}{l}\text { Butkhup et al. } \\
\text { (2012) }\end{array}$ \\
\hline & & $\begin{array}{l}\text { Alkali sericin extraction presented the best } \\
\text { antioxidant activity. }\end{array}$ & $\begin{array}{c}\text { Kumar \& Mandal } \\
(2017)\end{array}$ \\
\hline & & Sericin at 1 to $9 \mathrm{mg} / \mathrm{mL}$. & Fan et al. (2009) \\
\hline & & $\begin{array}{c}\text { Sericin and protease-hydrolyzed sericin is } \\
\text { studied }\end{array}$ & $\begin{array}{c}\text { Sangwong et al. } \\
(2016)\end{array}$ \\
\hline $\begin{array}{c}\text { ORAC (oxygen } \\
\text { radical } \\
\text { absorbance } \\
\text { capacity) } \\
\end{array}$ & $\begin{array}{l}\text { Bread with and without } \\
\text { sericin }\end{array}$ & $8 \mathrm{~g}$ sericin per $300 \mathrm{~g}$ bread. & $\begin{array}{l}\text { Takechi et al. } \\
\qquad(2014)\end{array}$ \\
\hline \multirow{2}{*}{$\begin{array}{c}\text { Flavonoids } \\
\text { quantification }\end{array}$} & \multirow{2}{*}{ Sericin from different strains } & $\begin{array}{l}\text { Extraction by different solvent were } \\
\text { studied. }\end{array}$ & $\begin{array}{c}\text { Napavichayanun et } \\
\text { al. (2017) }\end{array}$ \\
\hline & & $\begin{array}{l}\text { Sericin at } 1 \mathrm{mg} / \mathrm{mL} \text {. Different extraction } \\
\text { methods analyzed. }\end{array}$ & $\begin{array}{c}\text { Kumar \& Mandal } \\
(2017)\end{array}$ \\
\hline
\end{tabular}




\section{Conclusion}

Regarding to the methods reported in the literature to extract sericin, the use of high temperature, either by boiling water or using autoclave and posterior filtration, is efficient and a clean product is obtained. This technique is also economically convenient when compared to others more sophisticated methods of similar efficiency.

The antioxidant activity of sericin is mainly attributed to intrinsic properties of the protein, such as the amino acidic profile, which allows it to inhibit the tyrosinase enzyme, the lipid peroxidation and the oxidative stress and are associated to diseases such as cancer. Furthermore, sericin could act as natural food preservative due to the antioxidant potential commented, retarding the oxidative processes that affect the shelf life and quality of food. Therefore, sericin protein is an attractive multifunctional compound that might have not only benefits to the health when consuming, but also a protective effect to the food.

Further investigation is though required in terms of safety, to evaluate its use as functional food ingredient in the scope of regulatory authorities. Finally, considering that the sericin is a by-product from the silk manufacture, this protein has potential value from the economic and environmental point of view with promising biomedical and food applications.

\section{References}

Aghaz, F., Hajarian, H., Shabankareh, H. K., \& Abdolmohammadi, A. (2015). Effect of sericin supplementation in maturation medium on cumulus cell expansion, oocyte nuclear maturation, and subsequent embryo development in Sanjabi ewes during the breeding season. Theriogenology, 84(9), 1631-1635. PMid:26411362. http://dx.doi.org/10.1016/j.theriogenology.2015.08.013

Arami, M., Rahimi, S., Mivehie, L., Mazaheri, F., Mahmoodi, N. M. (2007). Degumming of Persian Silk with Mixed Proteolytic Enzymes. Journal of Applied Polymer Science, 106(1), 267-275. https://doi.org/DOI 10.1002/app.26492

Aramwit, P., Damrongsakkul, S., Kanokpanont, S., \& Srichana, T. (2010a). Properties and antityrosinase activity of sericin from various extraction methods. Biotechnology and Applied Biochemistry, 55(2), 91-98. PMid:20055756. http://dx.doi.org/10.1042/BA20090186

Aramwit, P., Kanokpanont, S., Nakpheng, T., \& Srichana, T. (2010b). The effect of sericin from various extraction methods on cell viability and collagen production. International Journal of Molecular Sciences, 11(5), 2200-2211. PMid:20559510. http://dx.doi.org/10.3390/ijms11052200

Butkhup, L., Jeenphakdee, M., Jorjong, S., Samappito, S., Samappito, W., \& Butimal, J. (2012). Phenolic composition and antioxidant activity of Thai and Eri silk sericins. Food Science and Biotechnology, 21(2), 389-398. http://dx.doi.org/10.1007/s10068-012-0050-0

Caleja, C., Barros, L., Antonio, A. L., Oliveira, M. B. P. P., \& Ferreira, I. C. F. R. (2017). A comparative study between natural and synthetic antioxidants: Evaluation of their performance after incorporation into biscuits. Food Chemistry, 216, 342-346. PMid:27596429. http://dx.doi.org/10.1016/j.foodchem.2016.08.075

Cao, T. T., \& Zhang, Y. Q. (2016). Processing and characterization of silk sericin from Bombyx mori and its application in biomaterials and biomedicines. Materials Science and Engineering C, 61, 940-952. PMid:26838924. http://dx.doi.org/10.1016/j.msec.2015.12.082

Capar, G., Aygun, S. S., \& Gecit, M. R. (2009). Separation of sericin from fatty acids towards its recovery from silk degumming wastewaters. Journal of Membrane Science, 342(1-2), 179-189. http://dx.doi.org/10.1016/j.memsci.2009.06.039

Castrillón Martínez, D. C., Zuluaga, C. L., Restrepo-Osorio, A., \& Álvarez-López, C. (2017). Characterization of sericin obtained from cocoons and silk yarns. Procedia Engineering, 200, 377-383. http://dx.doi.org/10.1016/j.proeng.2017.07.053

Chirila, T. V., Suzuki, S., Bray, L. J., Barnett, N. L., \& Harkin, D. G. (2013). Evaluation of silk sericin as a biomaterial: in vitro growth of human corneal limbal epithelial cells on Bombyx mori sericin membranes. Progress in Biomaterials, 2(1), 14. http://dx.doi.org/10.1186/2194-0517-2-14

Chlapanidas, T., Faragò, S., Lucconi, G., Perteghella, S., Galuzzi, M., Mantelli, M., Avanzini, M. A., Tosca, M. C., Marazzi, M., Vigo, D., Torre, M. L., \& Faustini, M. (2013). Sericins exhibit ROS-scavenging, anti-tyrosinase, anti-elastase, and in vitro immunomodulatory activities. International Journal of Biological Macromolecules, 58, 47-56. PMid:23541552. http://dx.doi.org/10.1016/j.ijbiomac.2013.03.054

Dash, R., Acharya, C., Bindu, P. C., \& Kundu, S. C. (2008). Antioxidant potential of silk protein sericin against hydrogen peroxide-induced oxidative stress in skin fibroblasts. BMB Reports, 41(3), 236-241. PMid:18377728. http://dx.doi.org/10.5483/BMBRep.2008.41.3.236

Deori, M., Devi, D., Kumari, S., Hazarika, A., Kalita, H., Sarma, R., \& Devi, R. (2016). Antioxidant effect of sericin in brain and peripheral tissues of oxidative stress induced hypercholesterolemic rats. Frontiers in Pharmacology, 7, 319. PMid:27695419. http://dx.doi.org/10.3389/fphar.2016.00319 
Doakhan, S., Montazer, M., Rashidi, A., Moniri, R., \& Moghadam, M. B. (2013). Influence of sericin/TiO2nanocomposite on cotton fabric: Part 1. Enhanced antibacterial effect. Carbohydrate Polymers, 94(2), 737-748. PMid:23544628. http://dx.doi.org/10.1016/j.carbpol.2013.01.023

Fan, J. B., Wu, L. P., Chen, L. S., Mao, X. Y., \& Ren, F. Z. (2009). Antioxidant activities of silk sericin from silkworm bombyx mori. Journal of Food Biochemistry, 33(1), 74-88. http://dx.doi.org/10.1111/j.1745-4514.2008.00204.x

Fan, J. B., Zheng, L. H., Wang, F., Guo, H. Y., Jiang, L., \& Ren, F. Z. (2010). Enzymatic hydrolysis of silk sericin by proteases and antioxidant activities of the hydrolysates. Journal of Food Biochemistry, 34(2), 382-398. http://dx.doi.org/10.1111/j.17454514.2009.00286.x

Freddi, G., Mossotti, R., \& Innocenti, R. (2003). Degumming of silk fabric with several proteases. Journal of Biotechnology, 106(1), 101-112. PMid:14636714. http://dx.doi.org/10.1016/j.jbiotec.2003.09.006

Gimenes, M. L., Silva, V. R., Vieira, M. G. A., Silva, M. G. C., \& Scheer, A. P. (2014). High Molecular Sericin from Bombyx mori Cocoons: Extraction and Recovering by Ultrafiltration. International Journal of Chemical Engineering and Applications, 5(3), 266-271. http://dx.doi.org/10.7763/IJCEA.2014.V5.391

Gonzalez, L., Fontalvo, M., Álvarez, C., \& Restrepo Osorio, A. (2014). Generalidades de la seda y su proceso de teñido. Prospectiva, 12(1), 7. http://dx.doi.org/10.15665/rp.v12i1.145

Gupta, D., Agrawal, A., Chaudhary, H., Gulrajani, M., \& Gupta, C. (2013). Cleaner process for extraction of sericin using infrared. Journal of Cleaner Production, 52, 488-494. http://dx.doi.org/10.1016/j.jclepro.2013.03.016

Jassim, K. N., \& Alsaree, O. J. (2010). Study of the antimicrobial activity of silk sericin from silkworm Bombyx mori. Iraqi Journal of Community Medicine, 23, 130-133.

Kaewkon, W., Aonsri, C., Tiyaboonchai, W., Pongcharoen, S., Sutheerawattananonda, M., \& Limpeanchob, N. (2012). Sericin consumption suppresses development and progression of colon tumorigenesis in 1,2-dimethylhydrazine-treated rats. Biologia, 67(5), 1007-1012. http://dx.doi.org/10.2478/s11756-012-0093-y

Kaewkorn, W., Limpeanchob, N., Tiyaboonchai, W., Pongcharoen, S., \& Sutheerawattananonda, M. (2012). Effects of silk sericin on the proliferation and apoptosis of colon cancer cells. Biological Research, 45(1), 45-50. PMid:22688983. http://dx.doi.org/10.4067/S0716-97602012000100006

Kato, N., Sato, S., Yamanaka, A., Yamada, H., Fuwa, N., \& Nomura, M. (1998). Silk protein, sericin, inhibits lipid peroxidation and tyrosinase activity. Bioscience, Biotechnology, and Biochemistry, 62(1), 145-147. PMid:9501526. http://dx.doi.org/10.1271/bbb.62.145

Khyade, V. B. (2016). Efficiency of Silk sericin from the cocoons of silkworm, Antheraea mylitta (L) and Bombyx mori (L) for treating the hydrogen peroxide induced oxidative stress in feline fibroblasts. World Scientific News, 44(44), 35-49.

Koh, L. D., Cheng, Y., Teng, C. P., Khin, Y. W., Loh, X. J., Tee, S. Y., Low, M., Ye, E., Yu, H.-D., Zhang, Y.-W., \& Han, M.-Y. (2015). Structures, mechanical properties and applications of silk fibroin materials. Progress in Polymer Science, 46, 86-110. http://dx.doi.org/10.1016/j.progpolymsci.2015.02.001

Kumar, J. P., \& Mandal, B. B. (2017). Antioxidant potential of mulberry and non-mulberry silk sericin and its implications in biomedicine. Free Radical Biology \& Medicine, 108, 803-818. PMid:28476503

http://dx.doi.org/10.1016/j.freeradbiomed.2017.05.002

Kumar, P., Kumar, D., Sikka, P., \& Singh, P. (2015). Sericin supplementation improves semen freezability of buffalo bulls by minimizing oxidative stress during cryopreservation. Animal Reproduction Science, 152, 26-31. PMid:25497424. http://dx.doi.org/10.1016/j.anireprosci.2014.11.015

Lamboni, L., Gauthier, M., Yang, G., \& Wang, Q. (2015). Silk sericin: A versatile material for tissue engineering and drug delivery. Biotechnology Advances, 33(8), 1855-1867. PMid:26523781. http://dx.doi.org/10.1016/j.biotechadv.2015.10.014

Li, H., Shi, W., Wang, W., \& Zhu, H. (2015). The extraction of sericin protein from silk reeling wastewater by hollow fiber nanofiltration membrane integrated process. Separation and Purification Technology, 146, 342-350. http://dx.doi.org/10.1016/j.seppur.2015.04.004

Li, Y. G., Ji, D. F., Chen, S., \& Hu, G. Y. (2008). Protective effects of sericin protein on alcohol-mediated liver damage in mice. Alcohol and Alcoholism, 43(3), 246-253. PMid:18263900. http://dx.doi.org/10.1093/alcalc/agm164

Mahmoodi, N. M., Arami, M., Mazaheri, F., \& Rahimi, S. (2010). Degradation of sericin (degumming) of Persian silk by ultrasound and enzymes as a cleaner and environmentally friendly process. Journal of Cleaner Production, 18(2), 146-151. http://dx.doi.org/10.1016/j.jclepro.2009.10.003

Manosroi, A., Boonpisuttinant, K., Winitchai, S., Manosroi, W., \& Manosroi, J. (2010). Free radical scavenging and tyrosinase inhibition activity of oils and sericin extracted from Thai native silkworms (Bombyx mori). Pharmaceutical Biology, 48(8), 855860. PMid:20673171. http://dx.doi.org/10.3109/13880200903300212

Micheal, A. S., \& Subramanyam, M. (2014). Influence of sericin in alleviating the hydrogen peroxide induced oxidative stress in silkworm Bombyx mori: Role of the amino acids. Information Systems Journal, 11, 257-272.

Napavichayanun, S., Lutz, O., Fischnaller, M., Jakschitz, T., Bonn, G., \& Aramwit, P. (2017). Identification and quantification and antioxidant activity of flavonoids in different strains of silk cocoon, Bombyx mori. Archives of Biochemistry and Biophysics, 631 , 58-65. PMid:28807613. http://dx.doi.org/10.1016/j.abb.2017.08.010

Oh, H., Lee, J. Y., Kim, M. K., Um, I. C., \& Lee, K. H. (2011). Refining hot-water extracted silk sericin by ethanol-induced precipitation. International Journal of Biological Macromolecules, 48(1), 32-37. PMid:20875446.

http://dx.doi.org/10.1016/j.jibiomac.2010.09.008 
Patel, S., \& Goyal, A. (2012). The current trends and future perspectives of prebiotics research: A review. 3 Biotech, 2(2), 115125. http://dx.doi.org/10.1007/s13205-012-0044-x

Pescio, F., Basso, C. P., Divo, M., Frank, R. G., Pelicano, A. E., \& Vieites, C. M. (2009). Manual para la producción. Buenos Aires: Instituto Nacional de Tecnologia Institucional.

Pisoschi, A. M., \& Pop, A. (2015). The role of antioxidants in the chemistry of oxidative stress: A review. European Journal of Medicinal Chemistry, 97, 55-74. PMid:25942353. http://dx.doi.org/10.1016/j.ejmech.2015.04.040

Prasong, S. (2011). Screening of antioxidant activity of some samia ricini (Eri) silks: Comparison with botnbyx mori. The Journal of Biological Sciences, 11(4), 336-339. http://dx.doi.org/10.3923/jbs.2011.336.339

Puangphet, A., Tiyaboonchai, W., \& Thongsook, T. (2015). Inhibitory effect of sericin hydrolysate on polyphenol oxidase and browning of fresh-cut products. International Food Research Journal, 22(4), 1623-1630.

Puangphet, A., Jiamyangyuen, S., Tiyaboonchai, W., \& Thongsook, T. (2018). Amino acid composition and anti-polyphenol oxidase of peptide fractions from sericin hydrolysate. International Journal of Food Science \& Technology, 53(4), 976-985. http://dx.doi.org/10.1111/ijfs.13672

Reddy, V., Urooj, A., \& Kumar, A. (2005). Evaluation of antioxidant activity of some plant extracts and their application in biscuits. Food Chemistry, 90(1-2), 317-321. http://dx.doi.org/10.1016/j.foodchem.2004.05.038

Rocha, L. K. H., Favaro, L. I. L., Rios, A. C., Silva, E. C., Silva, W. F., Stigliani, T. P., Guilger, M., Lima, R., Oliveira Junior, J. M., Aranha, N., Tubino, M., Vila, M. M. D. C., \& Balcão, V. M. (2017). Sericin from Bombyx mori cocoons. Part I: Extraction and physicochemical-biological characterization for biopharmaceutical applications. Process Biochemistry, 61, 163-177. http://dx.doi.org/10.1016/j.procbio.2017.06.019

Samaranayaka, A. G. P., \& Li-Chan, E. C. Y. (2011). Food-derived peptidic antioxidants: A review of their production, assessment, and potential applications. Journal of Functional Foods, 3(4), 229-254. http://dx.doi.org/10.1016/j.jff.2011.05.006

Sangwong, G., Sumida, M., \& Sutthikhum, V. (2016). Antioxidant activity of chemically and enzymatically modified sericin extracted from cocoons of Bombyx mori. Biocatalysis and Agricultural Biotechnology, 5, 155-161.

http://dx.doi.org/10.1016/j.bcab.2016.01.010

Sarovart, S., Sudatis, B., Meesilpa, P., Grady, B. P., \& Magaraphan, R. (2003). The use of sericin as an antioxidant and antimicrobial for polluted air treatment. Reviews on Advanced Materials Science, 5(3), 193-198.

Sasaki, M., Yamada, H., \& Kato, N. (2000). Consumption of silk protein, sericin elevates intestinal absorption of zinc, iron, magnesium and calcium in rats. Nutrition Research (New York, N.Y.), 20(10), 1505-1511. http://dx.doi.org/10.1016/S0271$5317(00) 80031-7$

Schinella, G. (2015). Los antioxidantes en la encrucijada: Mitos y realidades. Revista de Fitoterapia, 14(2), 115-126.

Silva, V. R., Ribani, M., Gimenes, M. L., \& Scheer, A. P. (2012). High molecular weight sericin obtained by high temperature and ultrafiltration process. Procedia Engineering, 42, 833-841. http://dx.doi.org/10.1016/j.proeng.2012.07.476

Sonjui, T., Noomhorm, C., \& Promboon, A. (2009). Sericin recovery from silk cocoon degumming wastewater by a membrane process. Witthayasan Kasetsat Witthayasat, 43(3), 538-549.

Sothornvit, R., Chollakup, R., \& Suwanruji, P. (2010). Extracted sericin from silk waste for film formation. Songklanakarin Journal of Science and Technology, 32(1), 17-22.

Srnivas, N., Kumar, R., \& Merchant, M. (2014). Extraction \& characterization of sericin and its immobilization on hydroxylapatite nanoparticles for tissue engineering applications. International Journal of Chemtech Research, 7(5), 2017-2124.

Suktham, K., Koobkokkruad, T., Wutikhun, T., \& Surassmo, S. (2018). Efficiency of resveratrol-loaded sericin nanoparticles: Promising bionanocarriers for drug delivery. International Journal of Pharmaceutics, 537(1-2), 48-56. PMid:29229512. http://dx.doi.org/10.1016/j.jpharm.2017.12.015

Suwannaphan, S., Fufeungsombut, E., Promboon, A., \& Chim-anage, P. (2017). A serine protease from newly isolated Bacillus $\mathrm{sp}$. for efficient silk degumming, sericin degrading and colour bleaching activities. International Biodeterioration \& Biodegradation, 117, 141-149. http://dx.doi.org/10.1016/j.ibiod.2016.12.009

Takechi, T., Wada, R., Fukuda, T., Harada, K., \& Takamura, H. (2014). Antioxidant activities of two sericin proteins extracted from cocoon of silkworm (Bombyx mori) measured by DPPH, chemiluminescence, ORAC and ESR methods. Biomedical Reports, 2(3), 364-369. PMid:24748975. http://dx.doi.org/10.3892/br.2014.244

Thongsook, T., \& Tiyaboonchai, W. (2011). Inhibitory effect of sericin on polyphenol oxidase and its application as edible coating. International Journal of Food Science \& Technology, 46(10), 2052-2061. http://dx.doi.org/10.1111/j.13652621.2011.02716.x

Wang, F., Cao, T. T., \& Zhang, Y. Q. (2015). Effect of silk protein surfactant on silk degumming and its properties. Materials Science and Engineering C, 55, 131-136. PMid:26117747. http://dx.doi.org/10.1016/j.msec.2015.05.041

Wang, R., Zhu, Y., Shi, Z., Jiang, W., Liu, X., \& Ni, Q. Q. (2018). Degumming of raw silk via steam treatment. Journal of Cleaner Production, 203, 492-497. http://dx.doi.org/10.1016/j.jclepro.2018.08.286

Wu, J. H., Wang, Z., \& Xu, S. Y. (2008). Enzymatic production of bioactive peptides from sericin recovered from silk industry wastewater. Process Biochemistry, 43(5), 480-487. http://dx.doi.org/10.1016/j.procbio.2007.11.018

Xing, R., Wang, F., Dong, L., Zheng, A. P., Wang, L., Su, W. J., \& Lin, T. (2016). Inhibitory effects of Na7PMo11CuO40on mushroom tyrosinase and melanin formation and its antimicrobial activities. Food Chemistry, 197(Pt A), 205-211.

PMid:26616942. http://dx.doi.org/10.1016/j.foodchem.2015.10.119 
Yakul, K., Takenaka, S., Nakamura, K., Techapun, C., Leksawasdi, N., Seesuriyachan, P., Watanabe, M., \& Chaiyaso, T. (2019). Characterization of thermostable alkaline protease from Bacillus halodurans SE5 and its application in degumming coupled with sericin hydrolysate production from yellow cocoon. Process Biochemistry, 78, 63-70. http://dx.doi.org/10.1016/j.procbio.2019.01.003

Yang, Y., Lee, S. M., Lee, H. S., \& Lee, K. H. (2013). Recovery of silk sericin from soap: Alkaline degumming solution. International Journal of Industrial Entomology, 27(1), 203-208. http://dx.doi.org/10.7852/ijie.2013.27.1.203

Yun, H., Kim, M. K., Kwak, H. W., Lee, J. Y., Kim, M. H., \& Lee, K. H. (2016). The role of glycerol and water in flexible silk sericin film. International Journal of Biological Macromolecules, 82, 945-951. http://dx.doi.org/10.1016/j.ijbiomac.2015.11.016

Zhao, J. G., \& Zhang, Y. Q. (2016). A new estimation of the total flavonoids in silkworm cocoon sericin layer through aglycone determination by hydrolysis-assisted extraction and HPLC-DAD analysis. Food \& Nutrition Research, 60(1), 30932. PMid:26979318. http://dx.doi.org/10.3402/fnr.v60.30932

Zhao, Z. L., Li, W. W., Wang, F., \& Zhang, Y. Q. (2018). Using of hydrated lime water as a novel degumming agent of silk and sericin recycling from wastewater. Journal of Cleaner Production, 172, 2090-2096. http://dx.doi.org/10.1016/j.jclepro.2017.11.213

Zhaorigetu, S., Sasaki, M., Watanabe, H., \& Kato, N. (2001). Supplemental silk protein, sericin, suppresses colon tumorigenesis in 1,2-dimethylhydrazine-treated mice by reducing oxidative stress and cell proliferation. Bioscience, Biotechnology, and Biochemistry, 65(10), 2181-2186. PMid:11758907. http://dx.doi.org/10.1271/bbb.65.2181

Zhaorigetu, S., Yanaka, N., Sasaki, M., Watanabe, H., \& Kato, N. (2003). Silk protein, sericin, suppresses DMBA-TPA-induced mouse skin tumorigenesis by reducing oxidative stress, inflammatory responses and endogenous tumor promoter TNF-alpha. Oncology Reports, 10(3), 537-543. PMid:12684620.

Züge, L. C. B., Silva, V. R., Hamerski, F., Ribani, M., Gimenes, M. L., \& Scheer, A. P. (2017). Emulsifying properties of sericin obtained from hot water degumming process. Journal of Food Process Engineering, 40(1), 1-10.

http://dx.doi.org/10.1111/jfpe.12267

Funding: None. 